\title{
Challenges of the Albanian Legislation on the Protection of Biodiversity
}

\author{
Erjon Muharremaj
}

Faculty of Law, University of Tirana, Albania

Copyright $\bigcirc 2016$ by authors, all rights reserved. Authors agree that this article remains permanently open access under the terms of the Creative Commons Attribution License 4.0 International License

\begin{abstract}
This paper strives to offer a brief overview of the challenges that Albania faces in its efforts to complete its legislation on the protection of biodiversity. It starts with a short introduction of the situation of the diverse flora and fauna of the country, and continues with an overview of the legal framework for the protection of biodiversity in Albania. Analyzing the efforts to harmonize its domestic legislation with the international environmental treaties, and because of the European integration process, with the acquis communautaire, the paper goes through the gradual changes that have been made in the Albanian legislation. Because of their particularly important role on the biodiversity protection, the analysis goes further with an overview of the legal framework for the protection of forests in Albania. In the end, the conclusions emphasize the importance of not only harmonizing the legislation on the biodiversity protection, but also of its strict implementation in practice.
\end{abstract}

Keywords Albania, Biodiversity, Environment, Legislation, Protection

\section{Introduction}

Even though Albania is one of the smallest countries in Europe, in the western part of the Balkan Peninsula, its climatic features, geographical position, the landscape and the hydrological and geological factors favor a great development of biodiversity. Its natural habitats offer adequate conditions for the existence of 7233 plant species (including firs, mushrooms, lichens, mosses, and algae), of which 3200 species of higher plants, around $32 \%$ of the European flora, and 5438 animal species (including birds, mammals, reptiles), of which 756 species of vertebrates. The lagoons near its coastline and the lakes within the country are important habitats, especially for the wintering of migrating birds. There can be found around 70 species of water birds, reaching around 180.000 of them during the winter. The country is also at the crossing routes of the migrating species, where it can be found around 91 globally endangered species, such as the Curly-headed pelican (Crispus crispus), the
Albanian Sea Turtle (Pelophylax shqipericus) and the Sturgeon (Acipenser sturio), for which Albania is of special importance. [1]

Unfortunately, the damages caused to the biodiversity are numerous, such as the loss and fragmentation of the habitats, damage, impoverishment and degradation of ecosystems and habitats, extinction of wild animals in their natural habitats, etc. The losses in biodiversity in Albania in the last 50 years are rated as among the highest in Europe. Damages have been caused even from the intensive gathering of medicinal plants, where Albania is ranked as the second exporter in Europe. Currently, 91 species have been listed as endangered. The most endangered ecosystems and habitats in Albania include the coast, estuaries, lagoons, coastal lakes, meadows, and alpine pastures. [2]

As a result of the undertaken initiatives, the protected areas cover today $15.8 \%$ of the territory of the country, with a surface area of 460.000 ha, where the lakes of Shkodra, Prespa, Butrint and Karavasta Lagoon are enlisted as Ramsar sites. However, this national network is still small to have a long-term effect in the protection of the biodiversity. Furthermore, the achieved level of protection in many protected areas is neither adequate, nor sufficient. In many of them, the illegal ways of exploitation such as logging, hunting or construction are widely spread.

In order to preserve the biodiversity, it is very important to expand the protected areas, with the aim of including all the types of ecosystems in this network, as one of the key elements of the sustainable development. The expansion and strengthening of the network of protected areas, as a grass root for the creation of the Ecologic Network of the country and as part of the European network, is considered as one of the most important objectives of the Action Plan for Biodiversity in Albania. [3] In this document, it is established as an objective the placement of $17 \%$ of the territory inside the protected areas, prioritizing marine areas. However, only the classification of the areas as "protected", without undertaking the necessary measures to guarantee in practice such protection, by providing the physical and human infrastructure for this purpose, would remain only a formal action, for the sake of "improving" statistics. 


\section{The Legal Framework for the Protection of Biodiversity in Albania}

Albania has become a party to the most important international treaties on biodiversity protection. It has adhered to the UN Convention on Biological Diversity (CBD), the Cartagena Protocol on Biosafety, and to the Ramsar Convention on Wetlands, the Bern Convention on the Conservation of European Wildlife and Natural Habitats, the Convention on International Trade in Endangered Species of Wild Fauna and Flora (CITES), the Convention on the Conservation of Migratory Species of Wild Animals, the UN Convention to Combat Desertification in Those Countries Experiencing Serious Drought and/or Desertification, Particularly in Africa (UNCCD), the Barcelona Convention for the Protection of the Mediterranean Sea Against Pollution, etc.

The Convention on Biodiversity requires the parties to establish strategies and action plans for the protection and the sustainable use of biodiversity, and establish systems of protected areas in which necessary measures must be undertaken for their protection. Pursuant to such requirements, the National Action Plan for the Protection of Biodiversity was adopted, which established the responsible authorities for the compliance with the obligations deriving from the Convention, and the regional and the local structures, such as the regional environment agencies, the regional forest directorates, and the Environment Inspectorate.

After the Action Plan, the Law "On Protected Areas" was adopted in 2002, followed by a specific law on biodiversity protection in 2006, both recently amended to be approximated with the relevant acquis communautaire. These laws stipulate the measures that shall be undertaken in the protected areas, with the aim of including them in the ecologic network Natura 2000. For the administration of the natural habitats and habitats of species, it is provided a list of areas of interest for the community, by identifying the habitat types and species in every respective bio-geographic region, with the aim of proposing the areas' list to the European Commission. (See Map of Protected Areas of Albania, Annex 1). For the designation of the national list, the law refers to the relevant Council of Ministers Decision on the approval of regulations concerning the special protection areas.

Despite the legal provisions that stipulate that within seven years from the adoption of the law, the responsible ministries for the environment and agriculture, in cooperation with other public authorities and with environmental non-governmental organizations shall designate the administration plans to hold or restore the favorable status of ecosystems' protection, only a few such plans have been drafted so far.

In the regional framework of the Council of Europe, Albania became a party to the Bern Convention on the Conservation of European Wildlife and Natural Habitats. The obligations stemming from the Convention aim at preserving the flora and fauna, their natural habitats, particularly species and lodging areas, including migrating species endangered from extinction and the unprotected ones. For the implementation of these obligations, the "Emerald" ecologic network was established in 1998 by the Council of Europe. The EU itself is a party to the Convention, hence this network is practically an extension of the Natura 2000 network, by including areas from the states that are not EU members. Even some African countries such as Algeria, Tunisia, Burkina Faso, Morocco, and Senegal hold the observer status in the meetings of the Permanent Committee of the Convention. The Emerald Network is based on the very same principles as Natura 2000, and for this reason it was proposed the inclusion of some new areas in this network, which was accepted by listing these areas as 'candidate areas' in 2011. [4]

In compliance with the obligations deriving from the Convention on Biodiversity, Albania has adopted numerous new laws, such as the law on forests and the forest service, on the pasture fund, on the protection of wildlife fauna, on the conservation of the fund of medicinal plants, on hunting, and because of the actual dire situation, a moratorium was enacted, enforcing a total ban on hunting for two years. The legal framework has been further completed with bylaws on the declaration of natural monuments as protected areas, on the administrations of protected areas, on procedures regarding the proposal and the declaration of the protected areas and buffer zones, on the approval of the list of species under protection, on the establishment of administration committees for protected areas, on the criteria for the establishment of the inventory and monitoring of the biodiversity network, on the approval of the list of foreign and invasive species, and the establishment of the procedures for the prohibition and their entrance in the customs, on the emergent measures of intervention and rehabilitation of the areas of national environmental importance, and so on.

In 1996 Albania became a party to the Ramsar Convention. To date, there have been four zones declared as protected areas of the convention: the Karavasta lagoon, the Butrint Lake, the Shkodra Lake, and the Prespa Lake. In each one of them are functioning the respective administrations and the management committees, which have drafted the management plans in collaboration with the local government authorities.

Albania adhered to the Convention to Combat Desertification (UNCCD) in 2000, by enacting a specific law for this purpose, whose legal provisions are mainly focused on land protection and land administration. The institutional framework established for the implementation of the Convention's provision includes the Ministry of Agriculture, the State Committee on Land Protection, the State Inspectorate on Land Protection, the district councils and the commissions on land protection. Their work is supported by scientific institutions, such as the Institute of Land Studies, whose main activity includes studies on the quality of the agricultural land, as part of the overall environment protection. Despite these efforts, land protection in Albania 
is not guaranteed, taking into consideration the massive process of illegal constructions on agricultural land, at a time when Albania cannot afford such "a luxury", because $2 / 3$ of its total area are covered by mountains. Taking also into consideration the extraordinary erosion levels due to the forests' extermination, it can be said that land protection efforts have been unsuccessful so far.

In order to enable Albania's participation in the ecologic network Natura 2000, another initiative was undertaken by amending the law on the protection of biodiversity, which was approximated with the Council Directive 92/43/EEC "On the conservation of natural habitats and of wild fauna and flora" (Habitats Directive), followed by the enactment of bylaws that approximate its annexes and the Directive 2009/147/EC (Birds Directive). The law provides for the obligation of the Ministry of Environment that in the framework of Natura 2000 should prepare every six years the report on the implementation of the protecting measures, including the conservation measures, the evaluation of their influence on the conservation of the species and of the natural habitats, plants and animals, as well as the main results achieved.

Albania adhered to the Bonn Convention on the Conservation of Migratory Species of Wild Animals in 2000, and also became a party to the agreements on the cetaceans (dolphins and whales), bats, and on the Euro-Asiatic migrating birds. In compliance with the obligations undertaken in the framework of these agreements, there have been drafted some specific action plans for the protection of five endangered fauna species such as cetaceans, lynx (Lynx lynx), brown bear (Ursus arctos), grouse (Alectoris graeca) and cormorant (Phalacrocorax pygmeus). [5] Further, a Red Book has been drafted, in which the endangered species are listed, whose capture or hunting is prohibited. The law on hunting declared the wild fauna as an important part of the national wealth, and proclaims as an objective the sustainable administration of hunting. Even though the law contains detailed provisions on the national development plan on hunting, hunting seasons, testing and requirements to obtain a hunting permit, and numerous administrative sanctions in case of non-compliance, unfortunately, due to the total disregard of the provisions of this law, a moratorium that absolutely prohibited hunting for two years became a necessity. The main objective of the moratorium is the prevention of the extinction of the wild fauna in Albania, which reached a critical situation after many years of abuse and hunting without criteria. [6]

Three years later, Albania adhered to the Convention on International Trade in Endangered Species of Wild Fauna and Flora (CITES), and following that, it enacted a law on establishing the regulations and procedures for the cross-border trade of the endangered flora and fauna species, in order to comply with the provisions of the Convention. According to these provisions, there are 3 annexes to the law: Annex 1: in which the species endangered from the extinction are listed and their trade is allowed only in exceptional circumstances; Annex 2, in which the species that are not necessarily endangered, are listed, the trade of these species shall be controlled in order to ensure their survival; and Annex 3 in which are listed the species that are protected at least from one state, and which has requested the assistance of the other states to control their trade. As for the institutional framework, the law divides it into administrative, scientific and controlling institutions. It assigns the Ministry of Environment as the administering body and as the authority responsible for the implementation of the Convention's provisions, the research-scientific institutions for fauna and flora as scientific authorities in the role of the advisers to the ministry, and the forest authorities, the Fishing Inspectorate and the Customs Service, as the controlling authority.

\section{Biodiversity Protection through the Protection of Forests in Albania}

It is a very positive fact that forests are being increasingly recognized as protectors of biodiversity, flora and fauna, and for their role in the economic development, in the provision of wood and non-wood forest products, firewood, medicinal plants, livestock feed, and for their ecologic, aesthetic, and leisure functions. They are important not only due to the fact that they cover over 4 billion hectares over the globe, equal to $31 \%$ of the total land area, but also because around 10 million people work in the forestry sector and over 1.6 billion people secure their livelihoods through forests. According to the statistics, 80 percent of the total forest area in the world is publicly owned, but their ownership and management by the communities themselves is increasing. [7] However, it must be taken into account that official statistics are not precisely true reflections of the situation on the ground, and that in many countries of the world, communities enjoy minimally informal rights of use over resources. [8]

The role of forests in maintaining biodiversity is irreplaceable. Statistics show that forests cover approximately one million hectares or about $36 \%$ of the total area of Albania. With the changes that occurred after the 1990's and the transformations towards the market economy, as in all other economic sectors of the country, even in the forest sector, the policies and legislation on forests and the environment needed a thorough revision. As part of the efforts to complete the legal framework, can be mentioned the law on forests, which has been amended several times (at the moment a new draft law has been presented to the Parliament by the government), the law on medicinal plants, the law on local governance, the law on public properties, etc.

According to the provisions of the EU Treaty, forest protection is not one of the areas under the competence of the Union, and as such, member states are not obliged to follow the same line of action, leaving thus the forest management under the competence of each member state. Under such conditions, the harmonization of forest policies can be 
achieved through the coordination of common policies of other sectors, such as the environment, energy, agriculture, industry, trade, etc. This has led the critics to argue about the inability to have a common line of action on forests, due to the distribution of policies into so many sectors within the EU.

On the other hand, all EU member states, as well as the Union itself as a whole, as an international organization, are parties to the Ministerial Conference on the Protection of Forests in Europe (MCPFE), which includes all other European countries and is the responsible body for the development of joint strategies concerning forestry in the European continent. It was at the Ministerial Conference held in Oslo, Norway, in June 2011, where ministers responsible for forests took the important decision to sign the negotiation mandate for drafting a binding agreement on forests in Europe.

The European Union, as a separate entity in international law, is a party to the Convention on Biodiversity, the Framework Convention on Climate Change and the United Nations Convention to Combat Desertification. Despite its internal fragmentation, the EU has established cooperation and coordination mechanisms related to forestry, on issues that bring consequences across national borders, including fires, forest diseases and trade in forest products. In the context of its European integration, Albania has become a party to two mechanisms of cooperation with the EU, through the Stabilization and Association Agreement (SAA) and the MCPFE, while in a broader context, is a party to all the international conventions mentioned above.

Given the decisive and multifunctional role that forests play in people's lives, contributing to their livelihoods, the impact on the climate and soil, as well as the function of the provider of sustainable energy and raw materials, a part of the environmental legislation is focused on the protection of forests. One of the first acts of the acquis communautaire in this regard was the Forest Strategy, set out in the Resolution 1999/C 56/01 of the Council, of 15.12.1998, "On a forestry strategy for the European Union", which was followed by the EU Action Plan on Forests. The main pillars of the Forest Strategy were based on the sustainable forest management, the principle of subsidiarity, the protection of the heritage of forests and biodiversity, as well as the increased efficiency in communication, coordination and cooperation between Member States. In terms of the EU enlargement, the strategy emphasized that the accession of the new states could be achieved only in respect of the mechanisms established on agricultural and rural development, including forestry.

Based on this action strategy, through Regulation 1085/2006, date 17.7.2006, the Council created the Instrument for Pre-Accession (IPA) for the candidate countries, which focuses on the adoption and full implementation of the acquis communautaire and the common agricultural policies of the Community. Albania is among the countries benefiting from the IPA, together with Turkey and other countries of the Western Balkans.

In order to guarantee the protection of forests and biodiversity from the effects of harmful natural phenomena, such as storms and fires, and because of the growing demand for food and raw material from the forests, and in order to respond to the challenges faced by the forest-based industries, a new strategy on forests became necessary. It was streamlined in the Communication from the Commission to the European Parliament, the Council, the European Economic and Social Committee and the Committee of the Regions, and it has as the guiding principles the sustainable forest management, among others, the resource efficiency, the optimization of the contribution of forests to rural development, growth and job creation, and the promotion of sustainable production and consumption of forest products. [9]

Since the signing of the SAA, Albania has taken a series of important reforms concerning the forest sector, in order to align its policies and legislation with the acquis communautaire. As a result of the efforts to depart from the legacy of the past, there are currently in place a number of strategies, and the process of approximation is continuous. However, the whole process has not been faultless, and it is inevitable the need for other measures, in order to face the increasing challenges related to the environment, in particular those concerning forests. Besides the achievements and positive developments, there are still present severe problems, such as illegal logging, destructive forest fires, grazing over permissible levels, erosion rates that lead to further degradation of forests, etc. The high informality in the Albanian economy is present in the forestry sector as well. In addition to problems inherited from the previous communist regime, the current situation, among other factors, it is partly due to the lack of policies and a complete legal framework, the lack of clear ownership titles, and the endemic problem of the failure of law enforcement.

Acting in accordance with obligations assumed under the Stabilization and Association Agreement, the European Strategy for Forests and the Pan-European Strategy for Biological Diversity and Landscape, Albania adopted in 2003 the National Strategy for Forests and Pastures, which sets out the main lines of action for the next 25 years. Among the stated objectives are listed the conservation and restoration of the natural balances of forest resources, the sustainable management of their products, ensuring a contribution as efficient as possible of this sector in the economic development, the fight against poverty and the sustainable development of the country.

As a result of the approximation process, some of the EU directives are transposed into the domestic law, but nevertheless, some important aspects are not included in the law on forests. For example, the privatization of forests and the sale of products derived from them are banned. Also, the process of forest restitution to former owners is progressing slowly, with no deadline set. Consequently, a review of the Strategy on Forests is needed, in order to include these important aspects for the sustainable development of forests.

Regulation 3528/86, date 17.11.1986, of the Council of 
the EU, which was amended in 1989, 1992 and 1997, focuses on the protection of forests, and creates a monitoring scheme for the damages caused by atmospheric pollution. In order to ensure the productivity of agricultural land, forests play an important role, because of the protection they offer to these lands. All member states must establish different monitoring zones, in order to create a network, in which through the continuous monitoring of forests, it can be evaluated the actual damage caused to forests by atmospheric pollution. The results are then provided to the Member States, in order to compile reports on the state of forests using the same scientific methods, which are subsequently submitted to the European Commission for assessment.

According to the Albanian law on forests, the monitoring is conducted by the National Environment Agency and the regional forest service departments. Throughout the country there have been set up a number of monitoring zones, but nevertheless, their number and the frequency of monitoring, along with devices made available for them, are insufficient. Moreover, there is a lack of funds needed for the prevention and elimination of the damage caused to forests.

Besides air pollution, another cause of damage to forests is fire, which is a serious obstacle to their sustainable development. In the context of measures taken in the fight against this negative phenomenon, the Council adopted the Regulation 2158/92, date $07 / 23 / 1992$, on the protection of the Community forests from fires, which was amended by the Regulation 308/97, date 17.02.1997. The aim of this regulation was to create a scheme for the protection of forests from fire, including the development of a database system for Member States and for the Community, in order to achieve the reduction of forest fires and the areas affected by them. The scheme also includes measures to identify the causes of forest fires, the improvement of the methods of fire prevention and of forest monitoring systems. For this purpose, it was established the European Information System on Forest Fires (EFFIS), serving not only the EU countries, but also the neighboring ones, providing information on forest fires throughout Europe. [10]

The National Strategy for Forest Fire Management in Albania has included the principles of Regulation 2158/92. Due to the high risk during the summer season, the number of supervisors has grown and a series of activities have been undertaken, in order to raise public awareness on the protection of forests from fire. However, forest fires remain a serious problem because of the shortage of infrastructure, equipment and funds. Albania is part of the high-risk area of fires of the Mediterranean, where in addition to natural causes, human activities aggravate the situation. Arson remains a serious problem for the country. During summer droughts, shepherds ignite fires in order to clear the area for new pastures, and this happens randomly. Despite legal provisions that stipulate penalties for arson, in reality, such punishments for damage caused to forests are rarely spelled out. Albanian legislation provides criminal sanctions for offences committed against forests, where Articles 205 and 206 of the Criminal Code stipulate that logging or damaging forests without permission is punishable by a fine or imprisonment up to one year. Given the aggravated situation because of the forest fires, the Criminal Code was amended and Article 206/a was added, which stipulates that the destruction or damaging of the forest, nursery forest, forest reserve or any other similar unit, caused intentionally by fire, is punishable by imprisonment three to five years and a fine of approximately 4,000-10,000 US dollars. The same act, committed with the intent of changing the category and destination of land, is punishable by imprisonment three to ten years and a fine of approximately 4,000-10,000 US dollars. The same act, when it has caused serious damages to the property, health or life of people or has caused severe and long-time damages to the environment or other protected areas, is punishable by imprisonment five to fifteen years and a fine of approximately 10,000-20,000 US dollars. As a comparison, it may be noted that Article 169/3 of the Turkish Constitution provides that "...no amnesties or pardons specifically for offences against forests shall be granted. Offences committed with the intention of burning or destroying forests or reducing forest areas shall not be included within the scope of amnesties or pardons. " [11] So, in Turkey, even people that have murdered maybe pardoned, but not the forest offenders.

Closely linked to forest protection is the protection of flora and fauna and with this aim it was adopted by the EU the Habitats' Directive, which urged the Member States to take economic and social measures to enhance the conservation of natural habitats and species. As previously analyzed, the Habitats' Directive requires the Member States to establish a network of protected areas, including areas of special protection and the adoption of certain measures which include special management plans for these areas, which must be integrated later in other development plans, together with other administrative measures.

All the above directives and regulations, including the Council Directive 409/79 on the conservation of wild birds, Directive 88/332/EEC of the Council on the marketing of seeds and Regulation 2152/2003 of the European Parliament and the Council on monitoring of forests, have been transposed into the Albanian domestic legislation through the law on forests.

Amendments to the law on forests made in 2007 added a whole new chapter, which stipulated the obligation to establish a monitoring and data system on forests, based on EU directives and the system used by FAO on the role of forests in carbon absorption. Amendments referred particularly to the Kyoto Protocol, where the Ministry of Environment has been designated as the authority responsible for monitoring, accounting and trading the carbon quotas. Currently, it is being prepared another draft law on forests, in order to provide a legal basis for the sustainable development, conservation, management, and harmonization of the information system on forests and pastures.

The law on forestry has also approximated the Regulation 995/2010, date 20.10.2010, of the European Parliament and 
the Council, the so-called "Due Diligence Regulation", which sets obligations for the operators trading timber and its products, in compliance of the EU Action Plan for Forest Law Enforcement and Trade (FLEGT). The purpose of the regulation is to prevent the entry into the market of timber and byproducts obtained illegally. The actual impact of these legal measures in Albania has been minimal because of the corruption even among authorities responsible for enforcing the law.

Through the high mountains of Albania, virgin forests still are of inestimable value in terms of biodiversity, the beauty of landscapes and natural monuments. Pursuant to the principles of Natura 2000, in these zones there have been established by law "Protected Areas", in which the use of timber is prohibited, and only certain types of activities can be developed, after obtaining a special permit. However, as in many other former communist countries, illegal logging of forests remains a high risk in Albania, as a constant threat to forests and biodiversity, which has led to massive deforestation and further degradation.

In Albania, half of the population is living in rural areas where the only source of energy for food and warming is fire, and consequently, the majority of these families are depended on the forests. The events of 1997, after the collapse of the pyramidal schemes that resulted in a total breakdown of law and order in Albania, had a devastating effect on forests, because of the massive activity of illegal logging. It is estimated that the quantity of logged forests was around $500,000 \mathrm{~m}^{3}$ only during the year 1997. [12] Today this quantity is around $10.064 \mathrm{~m} 3$. The actual situation of forests in Albania is so grave that the government has proposed to the Parliament the approval of a moratorium on cuts in the forests for 10 years, in order to stop further destruction.

In the European countries, private ownership covers over $50 \%$ of forests. In Albania, experience shows that private forests enjoy better management and protection than the public ones. In these circumstances, the legislation should allow further decentralization of the forest management, putting public forests in use and ownership of the subjects that have been traditionally using them, the villages and farming families who live by them. The village ownership of forests has a very old customary tradition in the country, which should be restored by law.

Among the fundamental aspects of the legal framework on forests, it has to be mentioned the transition from the planned and centralized economy into the market economy, the privatization of productive activities and services in forests, the realization of the transfer of $60 \%$ of the total forest area and $70 \%$ of the pasture area into the ownership of the local authorities.

In fact, the process of transition cannot be considered as complete, as there are still not legally recognized the borders between municipalities, villages, forests, and pastures, (more so in the current conditions of the territorial administrative reform), users have no documents to prove their exclusive rights of use on the forests or pastures, and these are not registered in the immovable property registration offices.

There has been a growing interest over the years to study the different regimes of common pool resources (CPR), and in this regard, to study the regimes applied on forests as one of the most important resources for the protection of biodiversity, and the role they play in the economic development. CPR theorists, Ostrom, Agrawal, Schlager, Hess, argue that there is no proof which shows that private property has advantages over common property, when it comes to sustainable management of common resources. They maintain that a distinction should be made between common property and open access, because it is upon the anarchical character of the latter that proponents of private property claim superiority. [13] When under management, common property limits the access only within a defined user group, to the exclusion of outsiders. Not only the right to access, but also the right to withdraw from the resource, to manage it, and the right to alienate it are considered as indispensable for the sustainable management of common pool resources. What's more interesting, there are cases when even within the same community, for one kind of resource is used one type of property title, e.g. private ownership over agricultural land, and a different type of property title for another kind of resource, e.g. pastures, depending on what is considered as most suitable and beneficial by the community. [14]

Furthermore, in the countries with weak governance, as it is the case of Albania, hybrid governance arrangements bringing together central and local institutions with the individuals that are the users of the resources, can be more effective than any isolated form of self-organization. [15] The state should move from the vertical initiatives following the hierarchical order, towards the community initiatives, the one that is closer to the resources. [16]

In fact, both private and common property institutions can guarantee the sustainable management of a common resource. They do not operate in isolation and are often combined with individual ownership. [17] On the other hand, neither of them, nor any type of property title can do that on their own, without them being secure, with an effective enforcement mechanism in place. [18] Also, the importance of institutions is paramount because they create the hospitable environment for cooperative solutions, reduce uncertainty by establishing stable structures for human interactions, and can make the violations of the rules costly and punishable. But in order to be successful, they also need to be adaptive and evolve with the time. [19]

As a result of the nationalization of the economies in the countries of the socialist camp, all natural resources became formally state property, but practically, they became open-access properties, leading to misuse and over consumption. In Albania, this very same phenomenon occurred with regard to the administration of forests. While there was no previous tradition of legal private property titles over forests, only $5 \%$ of them, the population considered the forests as open access resources, which could be used for the fulfilment of their practical needs, 
leading to their degradation that can still be witnessed today.

One of the main problems Albania is facing today is deforestation because of fires and overharvesting in those forests that are situated close to inhabited areas, whose impact is not only on forests, but on the entire environment as well. In order to fight this negative phenomenon, its roots need to be discovered.

The two main theories relative to deforestation are those of the population approach (which finds the root causes of deforestation in poverty and in the increase of population), and the market approach, which attributes deforestation to the market factors. [20] This is an area that needs careful research, because if the population approach were the right one, illegal loggers would not be the companies that are involved in the illicit trade, but people living at the subsistence level, trying to eke a living out of the forest. The market approach seems more plausible at first sight, but cannot explain the deforestation in Albania during the years of the centralized economy, when there was no market as it is today. These are questions that fall outside the scope of this paper, but will serve as the ground for further research, as part of the efforts to identify the importance of different historical processes, demographical changes, social and political factors that have an impact on the forest use in Albania.

\section{Conclusions}

From this analysis, it results that there are still many problems related to the Albanian legal framework on forests, which is not complete and does not provide the necessary legal certainty. The main problems are related to the ownership in forests and their privatization, the real and viable decentralization of the governance of the natural resources, and the legalization of the early informal possession of forests near the villages.

The actual legal provisions do not allow the privatization of the forests and there are no political orientations for moving towards the forests privatization. The ownership of forests and pastures is still unclear. Furthermore, there is inconsistency in the legal definitions of similar situations, regarding the forest and pastures ownership, such as: 'under ownership; 'under ownership and utilization' for forests, and 'under administration' for pastures. There is a centralization of competences in the central administration bodies for issues that can be delegated to the local government, such as the removal from the forest fund and the change of the land's utilization, permits, etc.

On the other hand, inconsistencies and overlaps exist on the competences of the administration and the cadastre of forests and communal pastures, relevant to the contraventions, sanctions, fees' collection, and environmental licenses. In the legal provisions, the ownership relations on forests between the central and local government are not regulated, as well as no criteria are defined for the transition from one form of property, to another. Also, there are no clearly defined relations between the local government and the forest users, between the forest service and the private owners. There is no system of incentives in place and direct profits that go to the users that follow practices of good governance of the natural resources, including the use of public forests.

Regarding forest protection, the Cross-Sectoral Strategy on the Environment provides for the continuous rehabilitation, the organization of a modern forest cadastre as a basis for the conservation of the forest fund as a whole, promoting sustainable use of forests and pastures, and the continuation of the transfer of user rights right over the properties by the local government. Despite the legal provisions, their practical and effective implementation remains problematic.

Because of the crucial role that forests play on the protection of the environment, the biodiversity, the impact on the climate change and on the country's economy, Albania should not only continue its efforts to approximate the national legislation with the acquis communautaire, but must ensure the effective implementation of such legislation, as the only way to succesfully realize the integration process into the European Union. 
Annex 1 - Map of Protected Areas of Albania (Source: Ministry of Environment)

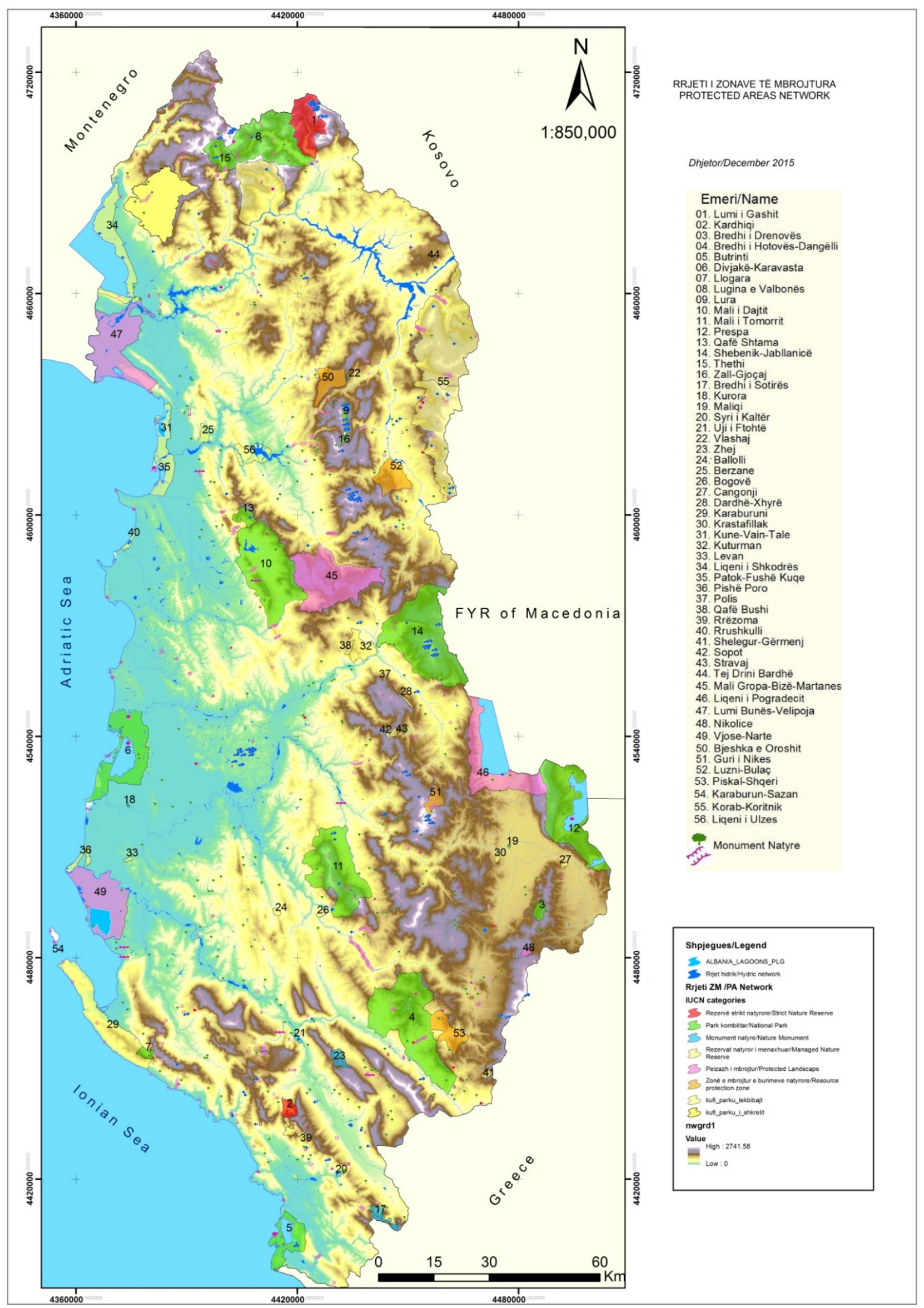




\section{REFERENCES}

[1] Albanian Strategic Document for the Protection of Biodiversity, 2015. Available at: http://www.qbz.gov.al/boti me/fletore_zyrtare/2016/PDF-2016/8-2016.pdf

[2] Vangjeli, Jani., Ruci, Babi., Mullaj, Alfred., "Red Book. Threatened and rare plant species of Albania", Academy of Science, Tirana, 1995.

[3] Albanian Inter-Sector Strategy of Environment, 2007. Available at: http://www.mjedisi.gov.al/files/userfiles/Strate gjia_Ndersektoriale_e_Mjedisit_2007.pdf

[4] The "Emerald" network. Candidate areas from Albania to be accepted in are available at: https://wcd.coe.int/com.instranet .InstraServlet?command $=$ com.instranet.CmdBlobGet\&Instra netImage $=1996948 \&$ SecMode $=1 \&$ DocId $=1773496 \&$ Usage $=2$

[5] Bino, T., Zoto, H., and Bego, F. 2006. "Shpendët dhe gjitarët e Shqipërisë”, Dajti 2000, Tirana.

[6] Law Nr. 7/2014, date 30.1.2014, "On the declaration of the hunting moratorium in the Republic of Albania".

[7] Food and Agriculture Organization (FAO). 2010. The Global Forest Resources Assessment, Main Report. Rome: Food and Agriculture Organization.

[8] Agrawal, A. 2007. Forests, Governance, and Sustainability: Common Property Theory and its Contributions. International Journal of the Commons 1 (1): 111-136.

[9] EU Forest Strategy. Available at: http://eur-lex.europa.eu/res ource.html?uri=cellar:21b27c38-21 fb-11e3-8d1c-01aa75ed7 1a1.0022.01/DOC_1\&format=PDF

[10] European Forest Fire Information System (EFFIS). Available at: http://forest.jrc.ec.europa.eu/effis/

[11] Constitution of Turkey. Available at: https://www.constitute project.org/constitution/Turkey_2011.

[12] REC (Regional Environmental Centre). 2010. Illegal Logging in South Eastern Europe. Szentendre, Hungary.

[13] Ostrom, E., and Hess, C. 2008. "Private and Common Property Rights." Encyclopedia of Law \& Economics. Available at: http://surface.syr.edu/cgi/viewcontent.cgi?articl $\mathrm{e}=1024 \&$ context $=$ sul

[14] Schlager, E., and Ostrom, E. 1992. Property rights regimes and natural resources: A conceptual analysis. Land Economics 68 (3): 249-262.

[15] German, L.A., and Keeler, A. 2010. "Hybrid institutions": applications of common property theory beyond discrete property regimes. International Journal of the Commons 4 (1): 571-596.

[16] Sikor, T., Müller, D., and Stahl, J. 2009. Land Fragmentation and Cropland Abandonment in Albania: Implications for the Roles of the State and Community in Post-Socialist Land Consolidation. World Development 37 (8): 1411-1423.

[17] Ostrom, E. 2000. Private and Common Property Rights. In Encyclopedia of Law and Economics, vol. II. Civil Law and Economics, eds. Bouckaert B. and DeGeest G., 274-314. Cheltenham: Edward Elgar.

[18] Tucker, C.M. 1999. Private versus Common Property Forests: Forest Conditions and Tenure in a Honduran Community. Human Ecology 27 (2): 201-230.

[19] Dietz, T., Ostrom, E., and Stern, P.C. 2003. The Struggle to Govern the Commons. Science 302: 1907-1912.

[20] Angelsen, A., and Kaimowitz, D. 1999. Rethinking the causes of deforestation: Lessons from economic models. World Bank Research Observer 14 (1): 73-98. 